\title{
A new species of Amblyseius Berlese (Acari: Phytoseiidae) from Brazil
}

Phytoseiid mites have received considerable world wide attention because of their potential as natural enemies of phytophagous mites (McMurtry, 1984). The Amblyseius obtusus group Chant is the largest species group in the genus Amblyseius. Chant \& McMurtry (2004) divided the group into seven subgroups based on spermathecal morphology. The andersoni subgroup of Chant \& McMurtry, 2004 is characterized by a spermatheca with the calyx dish-, cup-, bell-, or Vshaped, with the length/width ratio at the mid-point of the calyx $<3: 1$. A total of 24 species of the andersoni subgroup are known from the Neotropical region, 13 of these from Brazil (Moraes et al., 2004). A new species of this subgroup, Amblyseius paulofariensis sp. nov., is described and illustrated in this paper, from specimens collected in the semi-deciduous forest area of "Estação Ecológica de Paulo de Faria", a protected natural area in the State of São Paulo, southeastern Brazil, on three species of Euphorbiaceae: Acalypha diversifolia Jacq., Actinostemon communis (Müll. Arg.) and Alchornea glandulosa Poepp. \& Endl.. In the region where this mites was found, the climate is of the type Cwa-Aw of Köppen, with two distinct seasons: one wet, from October to March, and the other dry, from April to September. The annual mean temperature is $25^{\circ} \mathrm{C}$, with a maximum mean of $30^{\circ} \mathrm{C}$ and a minimum mean of $20^{\circ} \mathrm{C}$ (Barcha \& Arid, 1971; Arid \& Barcha, 1973).

Dorsal and ventral setal nomenclature is that of Rowell et al. (1978) and Chant \& Yoshida-Shaul (1991), respectively. All measurements are given in micrometres $(\mu \mathrm{m})$. The holotype measurements are shown in bold type followed by the mean and range in parentheses. The type specimens are deposited in the collection of Acari, Departamento de Zoologia e Botânica, Universidade Estadual Paulista (UNESP), São José do Rio Preto, State of São Paulo, Brazil (DZSJRP, http: //www.splink.cria.org.br).

\section{Amblyseius paulofariensis sp. nov.}

(Figs 1-7)

Material Examined. Holotype female, from Acalypha diversifolia Jacq. (Euphorbiaceae), April 14, 2003, "Estação Ecológica de Paulo de Faria”, State of São Paulo, Brazil, 1955'S, 49³1'W, R. Buosi coll. Paratypes: 3 females, 3 males from A. diversifolia, April 14, 2003; 4 females and 2 males from Actinostemon communis (Müll. Arg.) (Euphorbiaceae), May 30, 2003; 2 females from Alchornea glandulosa Poepp. \& Endl. (Euphorbiaceae), June 27, 2003. All paratypes from the same locality and collector as the holotype.

Diagnosis. Females of this species differ from other species of the andersoni subgroup found in the Neotropical region (except Amblyseius similicaudalis Karg and A. sylvestris Denmark \& Muma) by having setae JV2, ZV2 and ZV3 transversally aligned. It differs from A. similicaudalis and A. sylvestris by the shorter length of setae s4 and Z4, and by the shape of the spermatheca. Amblyseius paulofariensis sp. nov. most closely resembles A. igarassuensis Gondim Jr. \& Moraes, mainly in the shape of the spermatheca, but differs by having setae Z5 relatively shorter, the ventri-anal shield of the female pentagonal, wider than that of A. igarassuensis, and the dorsal shield slightly striated in the anterolateral region.

Description. Female (Figs 1-5) (10 specimens measured).

Dorsum (Fig. 1). Dorsal shield smooth, with a few striae anterolateraly, 317: 312 (296-326) long, $196: 199$ (194204) wide at level of s4; setae: j1 18: 19 (17-20), j3 33: 33 (30-36), j4 6: 6 (5-7), j5 6: 6 (5-6), j6 6: 7 (6-7), J2 8: 9 (810), J5 6: 7 (6-9), z2 10: 11 (9-13), z4 7: 9 (7-10), z5 6: 6 (5-7), Z1 9: 9 (8-10), Z4 54: 52 (48-56), Z5 79: 81 (75-87), s4 46: 47 (41-52), S2 11: 11 (9-12), S4 12: 12 (11-13), S5 12: 12 (11-14), r3 11: 11 (10-12), R1 8: 9 (8-10). All setae smooth, except Z4 and Z5 which are serrated.

Peritreme. Extending forward to the level of $\mathrm{j} 1$.

Venter (Fig. 2). Sternal shield smooth, with three pairs of setae and two pairs of lyrifissures; distance between st1st3 58: 59 (57-61) and between st2-st2 67: 67 (64-71). Genital shield smooth, distance between st5-st5 68: 67 (64-69). Ventri-anal shield smooth, nearly pentagonal, with lateral margins slightly concave posterior to ZV2; with three pairs of 